\title{
Effect of Sales Growth and Asset Structure on Capital Structure in Real Estate and Property Companies on the Indonesia Stock Exchange
}

\author{
Haljeki Aulia ${ }^{1 *}$, Lara Al Ashry ${ }^{2,}$ and Halkadri Fitra ${ }^{3}$ \\ ${ }^{1}$ Universitas Negeri Padang, Padang, Indonesia \\ (*) haljeki.aulia2019@gmail.com
}

\begin{abstract}
This study aims to analyze the effect of (1) sales growth and (2) asset structure on capital structure in real estate and property companies listed on the Indonesia Stock Exchange (IDX). This research is classified as causative research, using secondary data with a population of all real estate and property companies listed on the IDX in 2013-2017 and samples determined by purposive sampling method based on criteria (1) real estate and property companies listed on the IDX, (2) companies that publish financial statements during the year of observation and (3) companies that have net income during the year of observation to obtain 65 companies. Data analysis using multiple regression analysis using the SPSS program. The results of this study indicate that (1) sales growth has a negative and insignificant effect on the capital structure of real estate and property companies listed on the IDX and (2) the asset structure has a positive and significant effect on the capital structure of real estate and property companies listed on the IDX.
\end{abstract}

Keywords: capital structure, sales growth, asset structure

\section{Introduction}

Increasingly intense competition in the business world in the industrial 4.0 era, requires all companies to improve the superiority of the products produced, so as to increase the competitiveness of companies as an operating entity applying economic principles to increase the value of the company and the prosperity of its owners. Real estate and property companies listed on the Indonesia Stock Exchange experienced an increase from 40 companies in 2010 to 49 companies in 2016 (www.sahamok.com, 2017). The more real estate and property companies listed on the Indonesia Stock Exchange, the competition between companies will also be tougher, it will encourage companies to improve financial performance

Companies need funding to run and develop businesses. These sources of funding can be obtained from within and outside the company. Corporate funding decisions are one of the important decisions faced by company managers in the continuity of the company's operations. In determining the appropriate funding decision, it is necessary to pay attention to several things, namely: (1) decisions regarding the determination of the source of funds needed to finance investment, (2) the determination of the best expenditure balance or often called the optimum capital structure (Martono and Harjitno, 2010) .

Capital structure is the balance of permanent short-term debt, long-term debt, preferred stock and ordinary shares (Sartono, 2008). Capital structure is an important problem for every company, capital structure will have an impact on the company's financial position. Errors in determining the capital structure will affect the sustainability of the company, especially if the company is too large in using debt, then the burden that must be borne by the company is also greater. This can increase a company's financial risk if it cannot pay the interest expense or installments of its debt. According to Brigham and Houston (2011) "if the company wants to grow it needs capital, and capital in the form of debt and equity".

Capital structure can be measured from the ratio between total debt to own capital, commonly called the debt to equity ratio (DER) (Husnan and Pudjiastuti, 2015). This is consistent with the opinion of Brigham and Houston (2011) which states that DER shows the composition of debt to total 
equity. The use of DER is intended to facilitate measurement because the capital structure cannot be measured directly (Sartono and Sriharto, 1999). Given that DER in its calculation is debt divided by own capital, it means that if the company's debt is higher than capital itself means the DER ratio is more than one or the use of debt is greater in financing the company's activities than its own capital (Brigham and Houston, 2011).

In several Real Estate and Property companies listed on the Indonesia Stock Exchange in 2013-2017 experienced fluctuations in the company's capital structure, meaning that the level of debt of real estate and property companies experienced an increase and decrease as seen from the value of DER use of companies from 2013-2017. This phenomenon is also one reason researchers conduct research on capital structure because researchers want to know what are the factors that cause DER values during the year of observation to increase and decrease as PT Agung Podomoro Land Tbk from 2013 2017 has more than one DER value or usage greater debt in funding the company's activities means that the company's debt is higher than the capital itself. While PT Sentul City Tbk from 2013 - 2017 has a DER value of less than one or the use of smaller debt in funding the company's activities means that the company's debt is lower than the capital itself.

Factors that can influence the composition of the company's capital structure include asset structure, sales stability, growth rate, profitability, operating leverage, tax, control, management attitude, lender attitude and rating agent, market conditions, the company's internal conditions, financial flexibility (Brigham and Houston, 2011). The existence of factors that influence the company's capital structure is important as a basis for consideration in determining the composition of the company's capital structure. In this study, researchers only limited a number of factors to be investigated which allegedly had an effect on the capital structure namely sales growth and asset structure

Sales growth is a factor that influences the capital structure. The sales growth rate shows the rate of change in sales from year to year. The higher the growth rate, a company will rely more on external capital. A company whose sales are relatively stable will be safe in taking more debt and bear a higher fixed burden than companies whose sales are not stable (Brigham and Houston, 2011). In general, companies will need a lot of additional capital to expand their scale and market share. The higher the level of sales growth of the company, the greater the loan capital. Sales growth is measured by comparing the difference between sales in the current year and the previous year with the sales of the previous year (Kesuma, 2009).

Asset structure is related to the number of assets that can be used as collateral. Companies whose assets are sufficient to be used as collateral for loans, tend to use more debt because existing fixed assets can be used to determine how much debt can be taken and this will affect the determination of the size of the capital structure (Brigham and Houston, 2011). The asset structure is measured by comparing between fixed assets and total assets owned by the company or Fixed Asset Ratio (FAR).

Based on the above description and the differences in the results of previous studies regarding the factors that influence the capital structure encourage researchers to conduct research on the factors that influence capital structure by combining several variables including sales growth and asset structure with the title "Effect of Sales Growth and Asset Structure to the Capital Structure of a Real Estate and Property Company listed on the Indonesia Stock Exchange ". The research objective was to analyze the effect of sales growth and asset structure on the capital structure of real estate and property companies listed on the Indonesian stock exchange (BEI). Research contribution is the application of multiple regression methods to see the effect of sales growth and asset structure on the capital structure of real estate and Property companies on the Indonesia Stock Exchange

Funding decisions are related to the selection of funding sources both from within and from outside (Sekar; 2001). The source of company funds from the internal comes from retained earnings and depreciation. Funds obtained from external sources are funds originating from creditors and owners, participants or shareholders in the company. Fulfilling the needs of funds originating from credit is a debt to the company or referred to as the method of spending with debt. The funds 
obtained from the owners are their own capital. The proportion between the use of own capital and debt in meeting other company needs is called the company's capital structure.

Capital structure can be measured by the ratio of the ratio of total debt to own capital (Husnan and Pudjiastuti, 2015). Because the capital structure policy becomes important for the company, the company's financial managers need to identify the factors that influence the selection of capital structure.

According to Weston and Brigham (2005), companies with rapid sales growth tend to use debt more than companies that grow slowly. In addition, sales growth will affect creditors in providing loans, where companies that experience good sales growth are considered to have good prospects in their development and this reduces risk (Sofiati, 2001).

Companies that have a high level of sales growth certainly need additional funds to support this sales growth so that the use of funds will increase. According to the pecking order theory, companies prefer funding using sources originating from internal companies. Based on the pecking order theory, if the company has sales growth, then of course the company will have an internal source of funds from retained earnings which is the result of the company's sales growth. If the company tends to use retained earnings as a source of corporate funding, this will result in reduced debt usage in companies experiencing sales growth. Thus it can be concluded that sales growth can affect the capital structure of a company :

\section{H1: Sales growth affects the capital structure}

Brigham and Houston (2011) state that companies whose assets are suitable as collateral for loans tend to use debt more. According to Riyanto (2011) a company whose majority of its assets come from fixed assets, will prioritize meeting its funding needs with debt. Companies with a large number of fixed assets can use more debt, because fixed assets can be used as a good guarantee of company loans. Meanwhile, according to Lukas Atmaja (2008) companies that have relatively large fixed assets will tend to use foreign capital in their capital structure. This is done because fixed assets such as land, and buildings can be used as collateral for debt. Based on trade-off theory, companies will use debt to a certain point if the company has sufficient assets.

The use of corporate debt will increase when the condition of a company's fixed assets increases. Companies that have large amounts of fixed assets will prefer debt as a source of funding because these assets can be used as collateral. Thus it can be concluded that the higher the asset structure of the company shows the higher the ability of the company to be able to guarantee the debt borrowed. Conversely, the lower the asset structure of a company shows the lower the ability of the company to be able to guarantee its debt. In other words, the asset structure in the company has an influence in determining financing sources.

\section{H2: Asset structure affects the capital structure}

\section{Method}

The type of research used in this study is classified as causative research. This study seeks to explain the effect of sales growth and asset structure as independent variables on the company's capital structure as a dependent variable on Real Estate and Property companies listed on the Indonesia Stock Exchange.

The population that will be observed in this study are all Real Estate and Property Companies listed on the Stock Exchange in the period 2013-2017. Sampling in this study was conducted using purposive sampling method. The criteria of the companies that were sampled in this study were: Real Estate and Property Companies listed on the IDX, companies that had published financial statements during the year of observation, and companies that had net income during the observation year, namely 2013-2017. Based on these criteria, there are 13 Real Estate and Property companies included in the study sample in 5 years so the amount of data to be processed is 65 . To see the effect of the 
independent variables simultaneously on the dependent variable, a multiple regression equation ( $\mathrm{F}$ test) is used, while for testing the hypothesis and seeing the effect of each independent variable on the dependent variable, a partial test ( $\mathrm{T}$ test).

In this research the dependent variable $(\mathrm{Y})$ isCapital structurewhile the independent variables are Sales Growth (X1) and Asset Structure (X2). Capital structure (Y) is a balance between total debt and total equity, proxied by using Debt to Equity Ratio (DER), the following formula (Sartono, 2008):

\section{DER = Total of Debt /Total of Equity}

Sales growth $(\mathrm{X} 1)$ is an increase in the number of sales from year to year or from time to time, measured by the following formula:

Sales growth $=\left(\mathrm{S}_{\mathrm{t}}-\mathrm{S}_{\mathrm{t}-1}\right) / \mathrm{S}_{\mathrm{t}-1}$

Information :

$S_{t}=$ Current Year Sales

$\mathrm{S}_{\mathrm{t}-1}=$ Previous Year Sales

Asset structure (X2) is part of the amount of assets that can be used as collateral by the company to make loans to creditors, measured by Fixed Asset Ratio (FAR), the formula as follows:

FAR $=$ Fixed Asset $/$ Total of Asset

This study uses multiple regression analysis techniques, with the following equation:

$\mathrm{DER}=\mathbf{a}+\mathbf{b}_{1} \mathrm{PP}+\mathbf{b}_{2} \mathrm{FAR}+\mathrm{e}$

Information :

$\mathrm{Y}=$ Capital Structure

$\alpha$ : Constants

$\mathrm{b}_{12}$ : Independent Variable Regression Coefficient

PP :Sales Growth

e : Residual Variables (error rate)

\section{Results and Discussion}

Descriptive Statistics

This descriptive statistic is used to give an overview of the minimum value, maximum, average (mean), and standard deviation of each research variable, namely the debt to equity ratio (DER), sales growth (PP) and asset structure (FAR) a real estate and property company registered on the IDX. Descriptive results can be seen in Table 1 below:

Table 1. Descriptive Statistics of Research Variables

Descriptive Statistics

\begin{tabular}{|l|r|r|r|r|r|}
\hline & \multicolumn{1}{|c|}{$\mathrm{N}$} & Minimum & Maximum & \multicolumn{1}{c|}{ Mean } & Std. Deviation \\
\hline DER & 65 & .49 & 1.98 & 1.0238 & .37969 \\
PP & 65 & -.47 & 1.16 & .1671 & .28233 \\
FAR & 65 & .00 & .21 & .0626 & .05896 \\
Valid N (listwise) & 65 & & & & \\
\hline
\end{tabular}

Source: SPSS 16 Statistical Results 


\section{Classic Assumption Test}

\section{Normality Test}

The results of normality testing can be seen in Table 2 below:

Table 2. Normality Test

One-Sample Kolmogorov-Smirnov Test

\begin{tabular}{|ll|r|}
\hline & & $\begin{array}{c}\text { Unstandardized } \\
\text { Residual }\end{array}$ \\
\hline $\mathrm{N}$ & & 65 \\
Normal Parameters ${ }^{\mathrm{N}}$ & Mean & .0000000 \\
& Std. Deviation & .35021206 \\
Most Extreme Differences & Absolute & .121 \\
& Positive & .121 \\
& Negative & -.065 \\
Kolmogorov-Smirnov Z & & .975 \\
Asymp. Sig. (2-tailed) & & .298 \\
\hline
\end{tabular}

a. Test distribution is Normal.

Source: SPSS 16 Data Results

Based on Table 2, it can be seen that the test results state that the Kolmogrov-Smirnov value is 0.975 with a significance of 0.298 , so it can be stated that the data used in the study are normally distributed, because the significance value of the normality test for each variable is greater than 0.05 ( $0.298>0.05)$.

\section{Multicollinearity Test}

The results of the multicollinearity test can be seen in Table 3 .

Table 3. Multicollinearity test results

Coefficients $^{\mathrm{a}}$

\begin{tabular}{|c|c|c|c|c|c|c|c|}
\hline \multirow[t]{2}{*}{ Model } & \multicolumn{2}{|c|}{$\begin{array}{l}\text { Unstandardized } \\
\text { Coefficients }\end{array}$} & \multirow{2}{*}{\begin{tabular}{|c|}
$\begin{array}{c}\text { Standardized } \\
\text { Coefficients }\end{array}$ \\
Beta
\end{tabular}} & \multirow[b]{2}{*}{$t$} & \multirow[b]{2}{*}{ Sig. } & \multicolumn{2}{|c|}{$\begin{array}{c}\text { Collinearity } \\
\text { Statistics }\end{array}$} \\
\hline & B & Std. Error & & & & Tolerance & VIF \\
\hline $\begin{array}{ll}1 \quad \text { Constant } \\
& \text { ) }\end{array}$ & .893 & .071 & & 12.641 & .000 & & \\
\hline PP & -.117 & .158 & -.087 & -.741 & .461 & .998 & 1.002 \\
\hline FAR & 2.399 & .755 & .372 & 3.176 & .002 & .998 & 1.002 \\
\hline
\end{tabular}

a. Dependent Variable: DER

Source: SPSS 16 Data Results

The processing results presented in Table 3 show that all variables have a Tolerance value of more than 0.10 and Variance Inflation factor (VIF) is less than 10, so it can be concluded that there is no multicolonity between all the independent variables found in the study. 


\section{Heteroscedacity test}

Heteroscedasticity test using the Scatterplot graph method, the results are as follows:

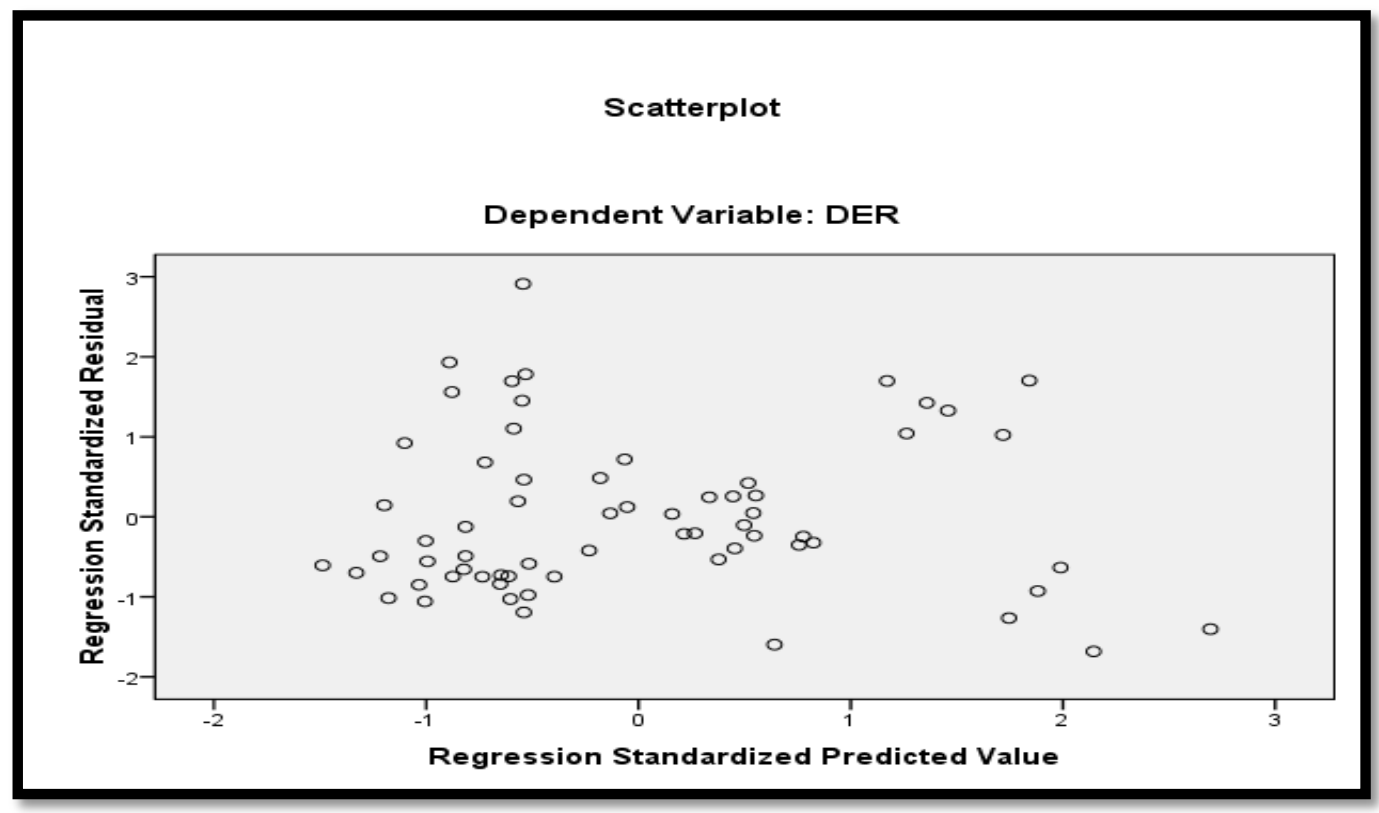

Figure 1. Scatterplot

Based on Figure 1, it can be seen that the Scatterplot points spread randomly and did not form a particular pattern so that it can be concluded that heterocedasticity did not occur in the regression model.

\section{Autocorrelation Test}

The autocorrelation test results can be seen in Table 4.

Table 4. Autocorrelation Test Results

\begin{tabular}{|l|r|r|r|r|r|}
\hline Model & $\mathrm{R}$ & \multicolumn{1}{|c|}{ R Square } & $\begin{array}{c}\text { Adjusted R } \\
\text { Square }\end{array}$ & $\begin{array}{l}\text { Std. Error of the } \\
\text { Estimate }\end{array}$ & Durbin-Watson \\
\hline 1 & $.386^{\mathrm{a}}$ & .149 & .122 & .35582 & .680 \\
\hline
\end{tabular}

a. Predictors: (Constant), FAR, PP

b. Dependent Variable: DER

Source: SPSS 16 Data Results

Based on the autocorrelation test in Table 4 it was found that the Durbin-Watson value was 0.680. Where the value is between $-2<0.680<+2$. These results indicate that the regression model does not have autocorrelation.

\section{Test of Multiple Regression Analysis}

In Table 5 is the result of multiple regression. 
Table 5. Multiple Regression Test Results

Coefficients $^{\mathrm{a}}$

\begin{tabular}{|c|c|c|c|c|c|}
\hline \multirow[t]{2}{*}{ Model } & \multicolumn{2}{|c|}{$\begin{array}{c}\text { Unstandardized } \\
\text { Coefficients }\end{array}$} & \multirow{2}{*}{$\begin{array}{c}\begin{array}{c}\text { Standardized } \\
\text { Coefficients }\end{array} \\
\text { Beta }\end{array}$} & \multirow[b]{2}{*}{$\mathrm{t}$} & \multirow[b]{2}{*}{ Sig. } \\
\hline & B & Std. Error & & & \\
\hline $\begin{array}{ll}1 \quad \text { Constant } \\
& \text { ) }\end{array}$ & .893 & .071 & & 12.641 & .000 \\
\hline PP & -.117 & .158 & -.087 & -.741 & .461 \\
\hline FAR & 2.399 & .755 & .372 & 3.176 & .002 \\
\hline
\end{tabular}

a. Dependent Variable: DER

Source: SPSS 16 Data Results

Based on the results in Table 5, the following equations can be formulated:

$\mathrm{DER}=0,893-0,117 \mathrm{PP}+2,399 \mathrm{FAR}$

\section{Determination Coefficient Test (R2)}

Based on Table 4, it can be seen that the Adjusted R2 value obtained is 0.122 . This shows that the capital structure (Debt to Equity Ratio) of real estate and property companies listed on the IDX can be explained by the independent variable namely sales growth. The asset structure profitability is $12.2 \%$, while the remaining $87.8 \%$ is determined by other variables, not analyzed in this study.

\section{F Statistics Test}

F Test Results can be seen in table 6 below:

Table 6. Test F

\begin{tabular}{|c|c|c|c|c|c|c|}
\hline & Model & Sum of Squares & $\mathrm{df}$ & Mean Square & $\mathrm{F}$ & Sig. \\
\hline \multirow[t]{3}{*}{1} & Regression & 1.377 & 2 & \multirow{3}{*}{$\begin{array}{c}.689 \\
.127\end{array}$} & \multirow[t]{3}{*}{5.439} & \multirow[t]{3}{*}{$.007^{\mathrm{a}}$} \\
\hline & Residual & 7.850 & 62 & & & \\
\hline & Total & 9.227 & 64 & & & \\
\hline
\end{tabular}

a. Predictors: (Constant),FAR, PP

b. Dependent Variable: DER

Source: SPSS 16 Data Results

Based on Table 14 it can be seen that the calculated F value is 5.439 with F Table of 3.15 then (5.439> 3.15) with a significance level of $0.007<0.05$. This means that there is a significant effect together between all the independent variables on the dependent variable. In addition, it can be concluded that this model is feasible to be tested.

\section{Hypothesis Test (t test)}

To find out the hypothesis is accepted or rejected by comparing the probability value with the value of $\alpha(5 \%)$. The criteria used to see the hypothesis are accepted or rejected by looking at the significance value $<0.05$ then the hypothesis is accepted. And if the significance value is $>0.05$, the hypothesis is rejected.

The first hypothesis in this study is sales growth influences the capital structure (DER) of real estate and property companies listed on the Stock Exchange in 2013 - 2017. Based on Table 5, it is known that the coefficient value of PP is negative 0.117 and the value of $t$ count is negative 0.741 with 
significance $0.461>0.05$. This means that sales growth has a negative and not significant effect on the capital structure of real estate and property companies listed on the Stock Exchange in 2013 - 2017, so it can be said that the first hypothesis was rejected.

The second hypothesis in this study is the asset structure influencing the capital structure (DER) of real estate and property companies listed on the Stock Exchange in 2013 - 2017. Based on Table 5 it is known that the asset structure coefficient value is positive 2,399 and the value of $t$ count is 3,176 with significance $0,002<0.05$. This means that the asset structure has a positive and significant effect on the structure of real estate and property capital listed on the IDX in 2013 - 2017. So it can be said that the second hypothesis is accepted.

\section{Effect of Sales Growth on Capital Structure (DER)}

Based on the results of the study, it can be seen that the sales growth variable has a negative and not significant effect on the capital structure (DER) in the real estate and property companies listed on the IDX for the period 2013 - 2017. The results are proven by the negative sales test results of 0.117 and $t$ values count is negative 0.741 with a significance of $0.461>0.05$. This significance value indicates that changes in the value of sales growth have no effect on changes in the company's capital structure (Debt to Equity Ratio).

The results of this study support the Pecking Order Theory, where the higher sales growth will use more internal funds in the form of retained earnings. This is certainly in accordance with the basic Pecking Order Theory concept which states that companies prefer internal funding compared to external funding. This condition shows the ups and downs of sales growth does not affect debt because the company does not use external funding but uses profits from within the company, namely profits obtained from sales that are used for company operations so that the company does not use debt. This is because the high level of sales does not tend to make the company to take debt and enlarge its capital structure.

The results of this study are consistent with the research conducted by Kesuma (2009) and the research of Puspawardani (2014) which states that sales growth has a negative and not significant effect on capital structure. But the results of this study do not support previous research conducted by Novione and Rusmala (2016) and the research of Farisa dan Widati (2017) which states that sales growth has a positive and significant influence on the company's capital structure. The higher the sales growth, the higher the ratio of debt usage by the company. The results of this study are not in accordance with the theory put forward by Weston and Brigham (2005) which states that companies with rapid sales growth tend to use debt more than companies that grow slowly.

\section{Effect of Asset Structure on Capital Structure (DER)}

Based on the results of the study it can be seen that asset structure variables have a positive and significant effect on capital structure (DER) in real estate and property companies listed on the Stock Exchange in the period 2013 - 2017. These results are proven by the FAR test results of a positive value of 2.399 and the calculated $t$ value is amounting to positive 3.176 with a significance of 0.002 $<0.05$. This significance value indicates changes in the value of asset structure affect changes in the company's capital structure (Debt to Equity Ratio).

The results of this study are in accordance with the theory suggested by Brigham and Houston (2011) which states that companies whose assets are suitable as collateral for loans tend to use debt more. This is because the fixed assets can be used as collateral if the company experiences financial difficulties so that the company will seek loans from outside. This is in accordance with a trade-off theory where the company will use debt as a source of funding for the company when the company has a good asset structure or has sufficient assets. The use of corporate debt will increase when the condition of a company's fixed assets increases. Companies that have large amounts of fixed assets will prefer debt as a source of funding because these assets can be used as collateral.

The results of this study are in line with the research conducted by Normawaty and Sonang (2017) which states that asset structure has a positive and significant effect on capital structure. In addition, 
the results of this study are also in line with the results of research by Andre and Karya (2014) and Putri (2012) which state that asset structure has a positive and significant effect on capital structure. With the similarity of these results, financial managers of real estate and property companies can pay attention to the company's asset structure in determining the combination of company funding as one of the things that affect the capital structure.

The results of this study contradict the results of research by Septiana (2014) and Zulvia (2016) stating that the asset structure has a negative and significant effect on capital structure. This is also not in line with the research of Harris and Raviv (1991) where companies with a high level of fixed assets are generally large companies, where the company can issue equity at a fair price so that it does not need to issue new debt. Conversely, companies with low fixed assets which are owned by small companies, of course, have a more expensive cost to issue new equity, because issuing new equity will only reduce their stock prices to be undervalued, so that debt is the best way.

\section{Conclusions}

The research conclusions are as follows: Sales Growth is known to have a negative and not significant effect on capital structure in real estate and property companies listed on the Indonesia Stock Exchange in the period 2013 - 2017. The asset structure is known to have a positive and significant effect the capital structure of real estate and property companies listed on the Indonesia Stock Exchange in the period 2013 - 2017.

The researcher gives advice to the next researcher in order to be able to conduct further research related to other factors that influence the company's capital structure. By replacing the research object, it may be sectoral or something else, and adding to the observation period, and it would be better to add other variables such as taxes, liquidity, ownership structure, dividend policy and others.

\section{Acknowledgments}

The researcher would like to thank Universitas Negeri Padang for this activity, hopefully it can be held every year. Then thanks are also conveyed to the family and all those who helped in this research.

\section{Reference}

Andre dan Karya. (2014). Pengaruh Profitabilitas, Struktur Aset dan Pertumbuhan Penjualan Terhadap Struktur Modal Serta Harga Saham. E-Jurnal Akuntansi Universitas Udayana 6.3 (2014): 514-530.

Atmaja, Lukas Setia. (2008). Teori dan Praktek Manajemen Keuangan. Yogyakarta: Penerbit ANDI

Brigham, Eugene F. dan Houston, Joel F. (2011). Dasar-dasar ManajemenKeuanganTerjemahan. Edisi 10. Jakarta: Salemba Empat.

Bursa Efek Indonesia. (2019). https://www.idx.co.id/perusahaan-tercatat/laporan-keuangan-dantahunan/. Tanggal 4 Januari 2019.

Eviani, Anantia Dewi.(2015). Pengaruh Struktur Aktiva, Pertumbuhan Penjualan, Dividend Payout Ratio, Likuiditas dan Profitabilitas Terhadap Struktur Modal. Jurnal Akuntansi dan Sistem Teknologi Informasi Vol. 11 No. 2 September 2015: 194-202.

Farisa, Nurul Anggun dan Widati, Listyorini Wahyu. 2017. Analisa Profitabilitas, Likuiditas, Pertumbuhan Penjualan, Struktur Aktiva Dan Kebijakan Dividen Terhadap Struktur Modal. Prosiding Seminar Nasional Multi Disiplin Ilmu. Vol. 3(3), pp. 640-649.

Fitra, Halkadri. (2017). Penggunaan Model Indeks Tunggal Untuk Iinvestasi Portofolio Saham di Bursa Efek Indonesia (Studi Kasus Pada Saham yang Terdaftar Pada Jakarta Islamic Index). Jurnal Economac Volume 1 Issue 1 April 2017. e- ISSN: 2549-9807 p-ISSN: 1412-3290. Padang

Ghozali, Imam. (2007). Aplikasi analisis multivariate dengan program SPSS. Badan penerbit UNDIP. Semarang.

Harris, M. dan Raviv, A. (1991).The Theory of Capital Structure.Journal of Finance,Vol. 46, No. 1, Maret: 297-355. 
Husnan, Suad dan Enny Pudjiastuti, (2015),Dasar-Dasar Manajemen Keuangan, Edisi Ketujuh. UPP STIM YKPN. Yogyakarta

Indriantoro, NurdanBambangSupomo,(1999).MetodologiPenelitianBisnissuntukAkuntansidanManajemen. Edisi 1. CetakanPertamaBPFE. Yogyakarta.

Kesuma, Ali. (2009). Analisis Faktor yang Mempengaruhi Struktur Modal serta Pengaruhnya Terhadap Harga Saham Perusahaan Real Estate yang Go-Public Di BEI.Jurnal Manajemen \& Kewirausahaan. Vol. II.No.1/Hal:38-45.

Khariry dan Yusniar. (2016) . Faktor-Faktor Yang Mempengaruhi Struktur Modal. Jurnal Wawasan Manajemen Vol. 4 Nomor 2 Juni 2016.

Martono and Harjitno. (2010). Manajemen Keuangan (Edisi 3). Yogyakarta: Ekonisia.

Normawaty dan Sonang. (2017). Pertumbuhan Perusahaan, Struktur aktiva, dan Pertumbuhan Penjualan Serta Pengaruhnya Terhadap struktur Modal. Jurnal ilmu dan Riset Manajemen Volume 6 Nomor 4.

Novione dan Rusmala Dewi. (2016). Pengaruh Pertumbuhan penjualan, Struktur Aktiva, dan Pertumbuhan Aktiva Terhadap Struktur Modal. E-jurnal manajemen unud. Vol 5. No 8.

Puspawardhani, Nadia. (2014). "Pengaruh Pertumbuhan Penjualan,Profitabilitas,Struktur Aktivadan Ukuran Perusahaan terhadapStruktur Modal pada Perusahaan Pariwisata dan Perhotelan di BEI".Jurnal, Universitas Udayana.

Putri, Meidera Elsa Dwi.(2012). Pengaruh Profitabilitas, Struktur Aktiva dan Ukuran Perusahaan terhadap Struktur Modal pada Perusahaan Manufaktur Sektor Industri Makanan dan Minuman yang Terdaftar di Bursa Efek Indonesia (BEI). Jurnal Manajemen, Volume 01, Nomor 01, September.

Riyanto, Bambang. (2011). Dasar-dasar Pembelanjaan Perusahaan. Edisi keempat Yogyakarta:BPFE.

Sartono, R. Agus. (2008). Manajemen Keuangan (Teori dan Aplikasi). Yogyakarta: BPFE.

Sartono, R. Agus dan Ragil Sriharto. (1999). Faktor-faktor Penentu Struktur Modal Perusahaan Manufaktur di Indonesia. Sinergi. Vol.2,Hal: 175-188.

Saswanto dan Lailatul. (2017). Pengaruh Profitabilitas, Struktur Aset dan Ukuran Perusahaan Terhadap Struktur Modal. Jurnal Ilmu dan Riset Akuntansi, Volume 6 Nomor 1.

Sekar, Mayangsari. (2001). Analisis Faktor-Faktor yang Mempengaruhi Keputusan Pendanaan Perusahaan: Pengujian Pecking Order Hipotesis. Media Riset Akuntansi, Auditing dan Informasi, vol I no 3 tahun 2001.

Septiana, Yeni, Dwi. (2014). Pengaruh profitabilitas, struktur aktiva, pertumbuhan penjualan, dan likuiditas perusahaan LQ45 di BEI. Fakultas Ekonomi Universitas Muhammadiyah Yogyakarta.

Sofiati. (2001). "Pengaruh Timbal Balik antara Utang dan Ekuitas Terhadap Struktur Modal Perusahaan-perusahaan Go-Publik di Bursa Efek Jakarta".Kompak. Yogyakarta: STIE Yo. (Januari) : 40-56.

Weston, J,F dan Brigham, E,F. (2005). Dasar-DasarManajemenKeuangan, EdisiKesembilan, Jilid 2, PenerbitErlangga, Jakarta.

Wing W. Winarno. (2009). Analisis ekonometrika dan statistika dengan eviews. Yogyakarta: Erlangga.

Zulvia, Yolandafitri. (2016). Determinan Struktur Modal. Jurnal Kajian Manajemen Bisnis, Vol. 5, No. 1, Maret 2016.

Yuliana dan Vivi. (2015). Pengaruh Risiko Bisnis, Ukuran Perusahaan dan Pertumbuhan Penjualan Terhadap Struktur Modal. E-Jurnal Manajemen Unud, Vol. 4 No. 5.

www.sahamok.com (2019). https://www.sahamok.com/laporan-keuangan-perusahaan-jasa/. Akses tanggal 10 Januari 2019 Pukul 23.00 WIB 